\title{
KAJIAN EVALUASI LAHAN HUTAN JATI SISTEM BONITA DI KESATUAN PEMANGKUAN HUTAN (KPH) CEPU
}

\author{
(The Study of Teak Forest Land Evaluation with Site Quality System \\ in The Forest Unit Management - KPH Cepu) \\ Heru Dwi Riyanto dan/and Uchu Waluya Heri Pahlana \\ Balai Penelitian Kehutanan Solo \\ Jl. Jend. A. Yani Pabelan, Surakarta \\ Telp. 0271-716709; Fax. 0271-716959
}

Naskah masuk : 09 September 2011; Naskah diterima : 10 Februari 2012

\begin{abstract}
Land evaluation method using forest inventory was conducted to study the characteristics of teak forest land in relation to teak productivity and degradation of teak forest land. This research was aimed at determining the dynamics of the changes of site quality (bonita) in the teak forest in Pasarsore and Cabak Sub Forest Management Units (BKPH), Cepu Forest Management Unit (KPH). The methode used is the site index system approach in which is the tree height and age plant as variable. The Forest inventory data will be tested to find out the relationship between the influence factors of the teak forest land and the stand potential. Site selection studies was considered at an catchment area of Sub Unit Watershed Management (DAS) level while the observation point was determined based on the age stand class (KU) and the site system of teak forests. Secondary data to determine the location were obtained from part of the forest management unit (RPKH), KPH Perum Perhutani. The results showed that the sites that have an increase in quality are $12.5 \%$, a decrease are $42.5 \%$ and $45 \%$ are still stable condition.
\end{abstract}

Keywords: Site index system, land evaluation, teakforest

\begin{abstract}
ABSTRAK
Evaluasi lahan dengan menggunakan metode inventarisasi tegakan dilakukan untuk mempelajari karakteristik lahan hutan jati dalam keterkaitannya dengan produktivitas tegakan jati dan kemungkinan terjadinya degradasi sumber daya lahan hutan jati. Tujuan dari penelitian ini adalah untuk mengetahui dinamika perubahan bonita pada hutan tanaman jati di Bagian Kesatuan Pemangkuan Hutan (BKPH) Pasarsore dan Cabak, Kesatuan Pemangkuan Hutan (KPH) Cepu. KPH Cepu. Metode yang digunakan adalah pendekatan bonita dengan parameter peninggi dan umur tanaman. Data hasil inventarisasi tegakan akan diuji korelasi untuk mengetahui hubungan dan pengaruh antara faktor lahan dan faktor potensi tegakan. Pemilihan lokasi kajian dipertimbangkan dalam suatu wilayah tangkapan air dengan tingkatan Sub-Sub DAS sedangkan titik pengamatan ditentukan berdasarkan kelas umur (KU) hutan jati dan bonita. Data sekunder untuk penentuan lokasi diperoleh dari RPKH Bagian Hutan, KPH Perum Perhutani. Hasil penelitian menunjukkan bahwa areal hutan jati yang mengalami peningkatan bonita sebesar $12,5 \%$, yang mengalami penurunan sebesar $42,5 \%$ dan yang tetap sebesar $45 \%$.
\end{abstract}

\section{Kata kunci : Bonita, evaluasi lahan, hutan jati}

\section{PENDAHULUAN}

\section{A. Latar Belakang}

Usaha penanaman tanaman jati secara komersial telah dimulai sejak jaman kolonial yang dilanjutkan oleh Perum Perhutani pada kawasan hutan negara. Penanaman jati pada kawasan hutan telah dilakukan secara mapan dengan membagi lahan hutan ke dalam petak yang didasarkan atas kelas kualitas lahan yang biasa disebut dengan istilah bonita. Pembonitaan atas kelas kualitas lahan berdasarkan parameter peninggi. Nilai bonita dapat digunakan sebagai 
indikasi kualitas lahan, dimana nilai bonita yang lebih tinggi menunjukan potensi lahan yang lebih baik. Suatu lahan yang mempunyai bonita tinggi untuk jati belum tentu sama bagi jenis lainnya.

Perubahan dinamika sumberdaya hutan juga terjadi di hutan jati Perum Perhutani sebagai akibat gangguan yang ditimbulkan dari interaksi hutan dengan faktor sosial ekonomi maupun faktor pengelolaan. Beberapa gangguan dari faktor sosial ekonomi adalah adanya pencurian/ penjarahan, penggembalaan liar dan kebakaran. Beberapa gangguan dari faktor pengelolaan diantaranya adalah penanaman jati secara monokultur terus menerus sehingga terjadi pengurasan unsur hara tertentu oleh tanaman jati yang diistilahkan sebagai jemu jati; kegiatan pemungutan kayu yang tanpa menyisakan sedikitpun biomassa tanaman untuk bahan dekomposisi sebagai input unsur hara; dan kegiatan tumpangsari tanpa perlakuan konservasi tanah dan air. Gangguan tersebut dapat menyebabkan degradasi kualitas lahan hutan yang terindikasi melalui penurunan kesuburan tanah dan penurunan bonita.

Pertumbuhan pohon secara individu atau dalam tegakan sangat ditentukan oleh kualitas tempat tumbuh (Simon, 2007). Masing-masing jenis tanaman menghendaki tempat tumbuh tersendiri karena tiap jenis tanaman mempunyai karakter tersendiri sehingga kualitas tempat tumbuh untuk setiap jenis tanamannya berbeda satu dengan yang lainnya (Parthama et al., 1999). Menurut Simon (2007), bahwa kualitas tempat tumbuh dipengaruhi oleh: sifat/kesuburan tanah, iklim dan faktor biotik. Tiga faktor tersebut akan berinteraksi bersama dengan suatu jenis tanaman menghasilkan suatu potensi produksi. Dari ketiga faktor yang dapat mempengaruhi kualitas tempat tumbuh, faktor kesuburan tanah merupakan faktor yang bersifat selalu berubah,sehingga faktor kesuburan tanah merupakan faktor yang dapat dimanipulasi untuk kepentingan peningkatan produktivitas sumber daya hutan (Simon, 2007).

Pengukuran kualitas tempat tumbuh sebagai langkah awal dan berperan penting dalam perencanaan pengelolaan hutan (Parthama et al., 1999). Oleh karena itu Simon (2007) menekankan pentingnya pengukuran kualitas tempat tumbuh dalam pengelolaan hutan tanaman dengan maksud: 1) untuk mengidentifikasi produktivitas tegakan dan 2) untuk menyajikan gambaran tentang rencana maupun pelaksanaan kegiatan teknik kehutanan. Program yang logis dan efektif dalam pengelolaan hutan yang intensif dengan tujuan meningkatkan pertumbuhan tidak dapat diimplementasikan tanpa ilmu yang memadai tentang hubungan timbal balik antara kondisi lahan dan produktivitas hutan (Sakurai et al., 2002). Senada dengan hal tersebut (Clutter et al., 1983) dalam Upadhyay (2007) menyatakan bahwa langkah awal dan penting dalam memprediksi pertumbuhan dan hasil adalah dengan mengkuantifikasikan perbedaan-perbedaan dalam kualita lahan. Dalam kaitan pengelolaan hutan (kayu), kualita lahan dapat diperkirakan sebagai potensi produksi kayu dari lahan untuk jenis tertentu atau tipe hutan tertentu.

Simon (2007) menyatakan bahwa untuk melakukan pengukuran dan penentuan kualitas tempat tumbuh ada 2 (dua) cara yaitu secara langsung dan tidak langsung. Pengukuran secara langsung dengan melakukan analisa terhadap faktor-faktor yang mempengaruhi produktivitas hutan seperti: kandungan hara tanah, tekstur dan struktur tanah, kelembaban, temperatur, topografi dan sebagainya. Di pihak lain pengukuran kualitas tempat tumbuh secara tidak langsung adalah dengan menggunakan bonita. Pendekatan bonita untuk menunjukan kualitas suatu lahan dapat cepat diketahui pada hutan tanaman yang telah dikelola secara baik. Bila lahan tersebut belum dikelola atau baru saja dilakukan penanaman maka akan menjadi pembatas untuk mengetahui kelas kualitas lahannya berdasarkan bonita. Selanjutnya, tanpa/ belum diketahuinya bonita suatu petak/lahan hutan maka akan menjadi penghambat dalam proses perencanaan dan pengelolaan tegakan hutan tanaman karena hampir semua strategi dan kebijakan pengelolaan didasarkan pada bonita (Parthama et al., 1999).

Lahan adalah fenomena penting dalam hutan alam maupun hutan tanaman, yang direfleksikan oleh pertumbuhan dan perkembangan tegakan hutan. Aspek tanah dan iklim adalah dua faktor utama yang mempengaruhi karakter lahan dalam tanaman. Dalam kajian kehutanan kualita lahan dievaluasi dengan bantuan indek yang berbeda. Tidak ada indek tunggal berdasarkan parameter-parameter lingkungan secara langsung (Sajjauzzaman et al., 2005).

Site index adalah konsep tertua yang telah berkembang dan dapat diterima dalam mengevaluasi produktivitas lahan tegakan hutan (Husch et al., 1972, Smith dan Watts, 1987) dalam Akindele, 1991). Site index didefinisikan sebagai rata-rata tinggi total pohon-pohon 
tertentu dalam suatu tegakan pada saat umur tertentu (Powers, 1973) dalam Akindele (1991). Peninggi (dominant height) didefinisikan sebagai tinggi rata-rata (secara aritmatika) dari seratus pohon dengan basal area terbesar per hektar (Akindele, 1991). Estimasi side index ("bonita" atau kualitas lahan dari jati) yang didasarkan pada tinggi pohon dan umur seringkali terkendala oleh keakuratan pengukuran peninggi dan ketepatan umur tanaman (Spur, 1952; Davis, 1966) dalam Anwar, 2007. Adalah tidak mungkin untuk mengumpulkan data tersebut ketika belum ada pohonnya. Kondisi tersebut yang muncul dalam pengelolaan Jati di Indonesia. Produktivitas tidak dapat secara baik diprediksi berdasarkan situasi terdahulu, atau pada lahan- lahan kosong yang mungkin saja sesuai untuk penanaman jati.

\section{B. Tujuan Penelitian}

Tujuan penelitian ini adalah untuk mengetahui dinamika perubahan bonita pada hutan tanaman jati.

\section{METODOLOGI}

\section{A. Lokasi Penelitian}

Penelitian ini dilakukan di Kabupaten Blora, Provinsi Jawa Tengah pada tahun 2010, tepatnya di KHDTK Cemoro Modang yang terletak pada wilayah kerja Bagian Kesatuan Pemangkuan Hutan (BKPH) Pasarsore dan
BKPH Cabak, Kesatuan Pemangkuan Hutan (KPH) Cepu, Perum Perhutani Unit I Jawa Tengah, tersaji pada Gambar 1.

\section{B. Bahan dan Alat}

Bahan yang digunakan dalam penelitian ini antara lain :

- Peta : peta RBI, peta petak kawasan hutan, peta administrasi, peta geologi.

- Data potensi kondisi tegakan hutan jati dalam Rencana Pengaturan Kelestarian Hutan (RPKH) Bagian Hutan Tahun 2003-2013

- Bahan ATK dan komputer: blangko Talysheet, ballpoint, kertas, tinta, kertas plotter, USB dan hard disk eksternal

Adapun alat yang digunakan antara lain : GPS, haga meter, kompas, abney level, altimeter dan meteran.

\section{Penetapan Lokasi Kajian dan Parameter yang Diamati}

Lokasi kajian ditentukan dengan cara membatasi kawasan hutan dengan satuan daerah tangkapan air tingkat Sub-Sub DAS. Di dalam lokasi kajian tersebut kemudian ditentukan titiktitik sampling berupa unit lahan dalam suatu petak hutan secara purposive berdasarkan dua faktor yaitu kelas umur (KU) jati dan bonita dengan masing-masing tiga ulangan. Faktor kelas umur meliputi KU I, II, III, IV, V, VI, VII dan VIII, dengan pemilihan umur tegakan pada suatu kelas umur ditentukan dengan rentang tahun tanam yang tidak jauh. Faktor bonita meliputi III,

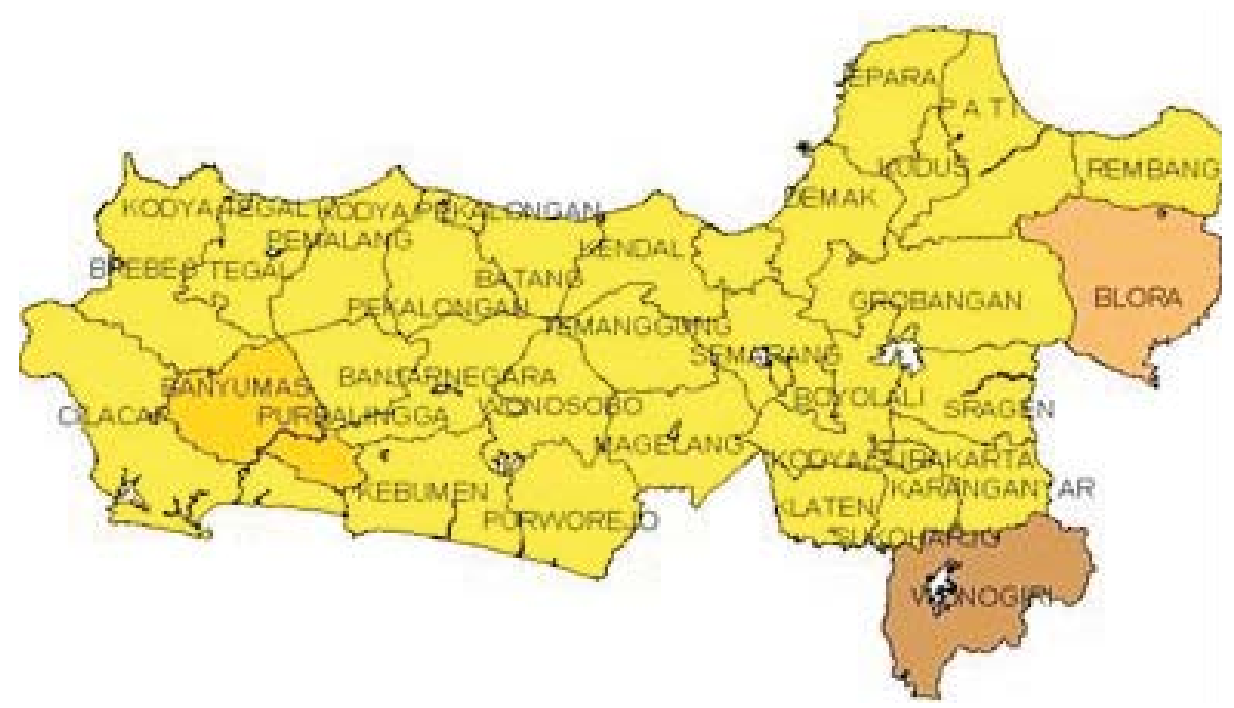

Gambar(Figure) 1. Lokasi penelitian di KPH Cepu, Kabupaten Blora (Research location in KPH Cepu, Blora Regency) 
III/IV, IV. IV/V dan V, sehingga jumlah titik sampling yang dibuat sebanyak 120 buah titik sampling dengan perhitungan sebagai berikut $=8$ (delapan) faktor KU x 5 (lima) faktor bonita x 3 (tiga) ulangan. Penentuan titik sampling bersumber dari data potensi hutan dalam Rencana Pengaturan Kelestarian Hutan (RPKH) Bagian Hutan tahun berjalan. Parameter yang diukur/diamati adalah tinggi/peninggi dari umur tanaman yang dipilih.

\section{Analisa Data}

Data umur dan pengukuran tinggi tanaman akan digunakan untuk menentukan bonita. Analisa deskriptif digunakan untuk mengetahui dinamika perubahan bonita terkait dengan terjadinya penurunan degradasi lahan melalui pengumpulan data bonita tiap petak dalam
Sub-Sub DAS kajian dari RPKH Bagian Hutan.

\section{HASIL DAN PEMBAHASAN}

\section{A. Sebaran Petak Sampel}

Penelitian yang dilakukan di sub DAS Cemoro-Modang dan sekitarnya ini dilakukan dengan membuat petak pengamatan. Sebaran petak pengamatan tersebut didasarkan atas data potensi perum Perhutani sesuai dengan kelas umur dan bonita. Dalam petak pengamatan yang berukuran 0,1 hektar dilakukan pengukuran peninggi dan pencinderaan lahan guna menentukan Kelas Penggunaan Lahan (KPL) dan Kelas Kesesuaian Lahan (KSS). Sebaran petak pengamatan tertera pada Gambar 2.

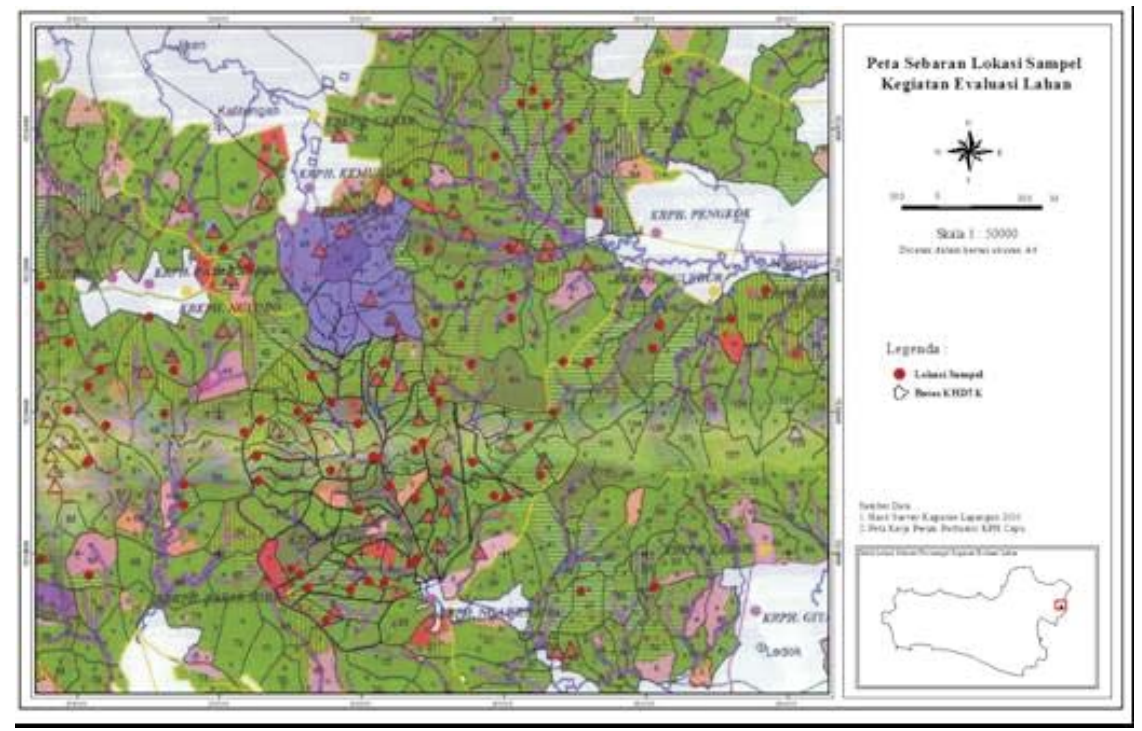

Gambar (Figure) 2. Sebaran lokasi petak sampel (Location of sample plot)

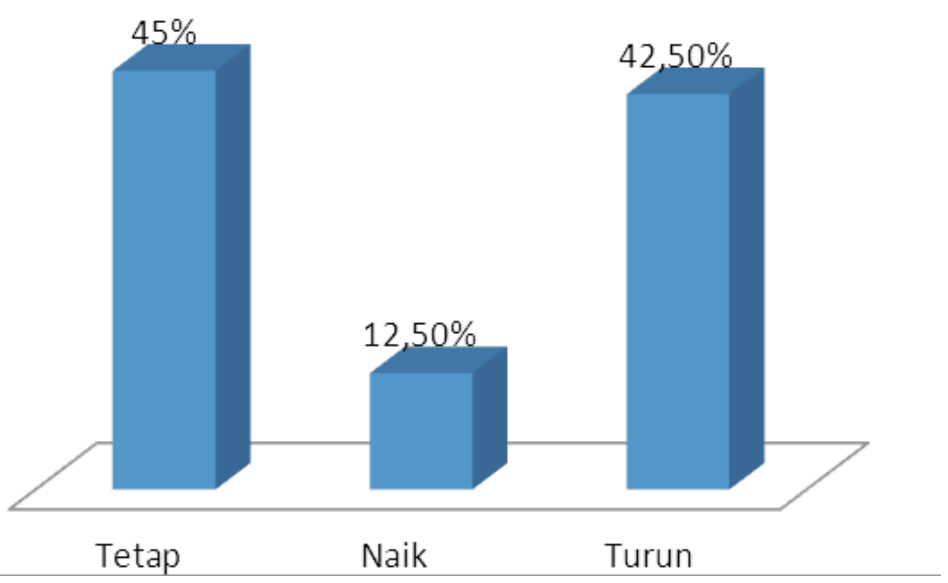

Gambar (Figure) 3. Perubahan bonita pada hutan jati (Site quality changes in the teak forest). 
Hasil dari nilai peninggi hasil pengukuran pada masing-masing petak pengamatan apabila dihubungkan dengan tabel Wolf Von Wolfing (WVW) telah terjadi perubahan bonita secara umum sebesar 55\%. Secara lebih terinci perubahan menjadi lebih baik sebesar $12,5 \%$ dan yang mengalami penurunan sebesar $42,5 \%$, sdangkang yang tetap sebesaar $45 \%$. Menurut Puslitbang Perum Perhutani (2007), berdasarkan pengamatan pada lampiran RPKH selama tiga jangka (30 tahun) di KPH Randublatung pada $\mathrm{BH}$ Banglean dan Ngliron menunjukkan terjadi penurunan bonita sebesar $37 \%$ dari petak yang ada. Potensi Sumber Daya Hutan (SDH) yang dikelola Perum Perhutani dari tahun ke tahun semakin menurun. Salah satu faktor penyebabnya adalah menurunnya kesuburan/ kualitas tapak (Yunianto dan Muhadi, 2010). Kualitas dan kesuburan tanah sebagian besar tapak penanaman hutan jati telah mengalami penurunan (Sukresno, et al., 2003) Hal tersebut dikarenakan kurang diperhatikannya faktor tapak oleh manajemen dalam pengelolaan hutan.

Dalam pembangunan hutan tanaman jati seringkali tidak memperhatikan kaedah-kaedah konservasi tanah, sehingga menyebabkan penurunan kualitas tanah. Hutan tanaman jati dikelola dengan prinsip kelestarian hasil (sustained yield principle), yaitu menghasilkan kayu secara lestari dengan kuantitas dan kualitas yang tidak menurun. Kelestarian hasil ini akan dapat tercapai bila kelestarian produktivitasnya terjaga. Produktivitas merupakan hasil interaksi antara kualitas tapak (site index) dan manajemen yang mengelola hutan tanaman atau praktek silvikultur yang diterapkan. Penurunan kualitas lahan secara terus menerus dapat menyebabkan penurunan potensi sumberdaya hutan.

Perubahan kualitas tapak tersebut disebabkan oleh perubahan kesuburan tanah yang merupakan dampak dari erosi, sedimentasi, penggembalaan, kebakaran hutan, pencurian, pemupukan, penggunaan jenis unggul, perubahan kelas perusahaan hutan dan lain-lain (Puslitbang Perum Perhutani, 2007). Faktor erosi dan sedimentasi akan berpengaruh pada penurunan kesuburan tanah dan penurunan kapasitas tanah dalam menyerap dan menyimpan air. Hilangnya top soil yang merupakan lapisan tanah yang subur akan menyebabkan penurunan kesuburan tanah. Menurut Yunianto dan Muhadi (2010), laju limpasan permukaan pada hutan jati KU muda lebih tinggi dibandingkan dengan limpasan permukaan yang terjadi pada KU tua, terutama pad KU VIII. Hal ini menunjukkan bahwa penurunan kualitas lahan pada hutan jati terjadi pada KU I sampai KU VII. Hasil penelitian menunjukkan bahwa sebagian besar KU yang mengalami penurunan kulitas lahan berada pada selang KU II sampai KU VII.

\section{B. Hubungan Bonita dan Peninggi}

\section{Teknik Grafik}

Dengan menempatkan besaran peninggi pada sumbu Y (peninggi) dan sumbu X (bonita) akan diperoleh sebaran titik-titik, yang selanjutnya dilakukan penglinieran sehingga diperoleh garis lurus yang menempati antara titik-titik tersebut, dan sekaligus diperoleh besaran nilai keeratan hubungan (R) antara peninggi dan bonita. Hasil tersebut disajikan dalam Gambar 4 sampai Gambar 10.

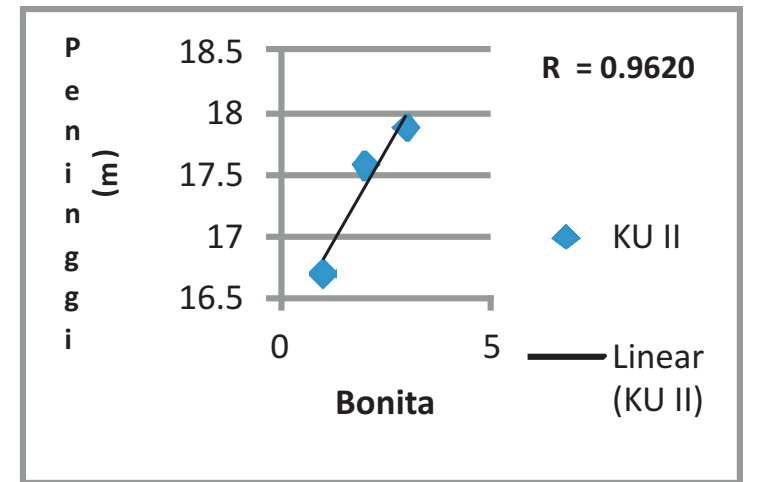

Gambar(Figure) 4. Peninggi KU II (The higest tree of $K U I I)$

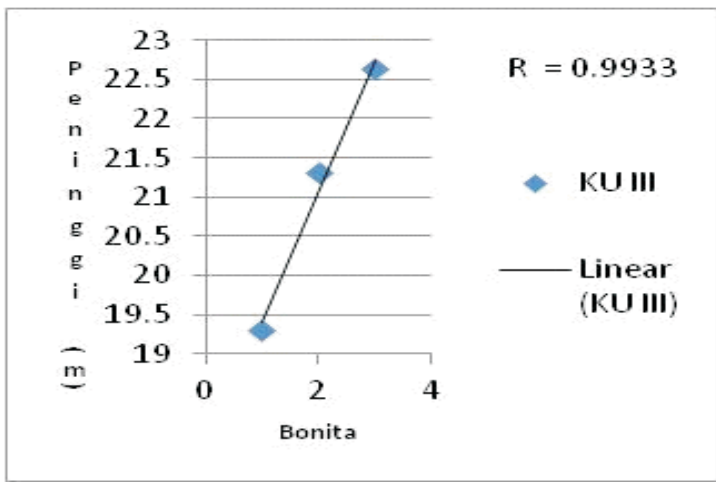

Gambar(Figure) 5. Peninggi KU III (The higest tree of $K U$ III) 


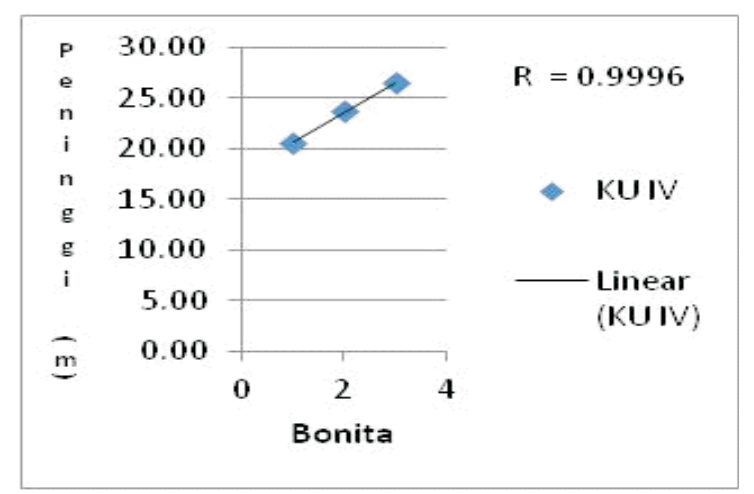

Gambar(Figure) 6. Peninggi KU IV (The higest tree of $K U I V)$

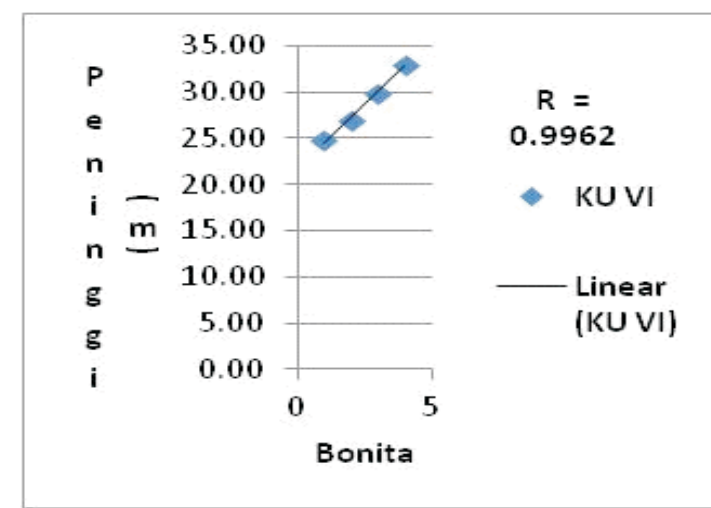

Gambar(Figure) 8. Peningg KU VI (The higest tree of $K U V I)$

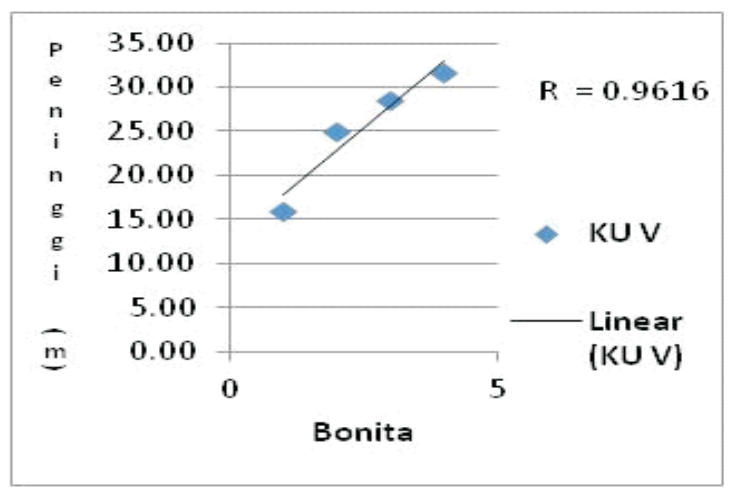

Gambar (Figure) 7. Peninggi KU V (The higest tree of $K U V$

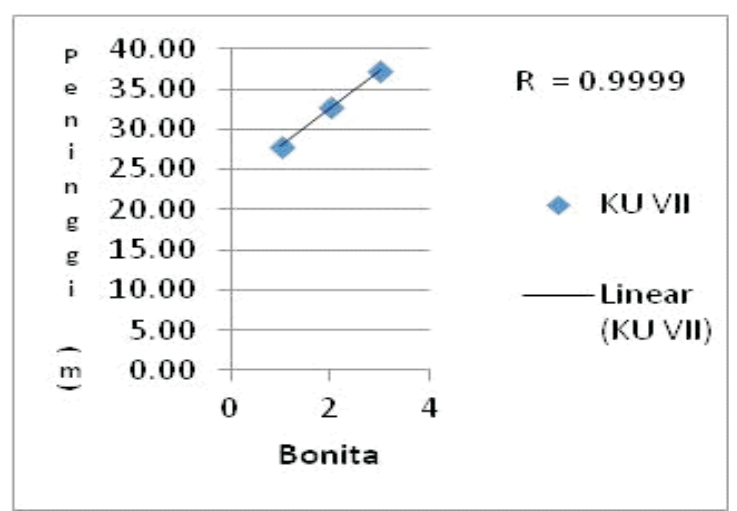

Gambar(Figure) 9. Peninggi KU VII (The higest tree of $K U V I I)$

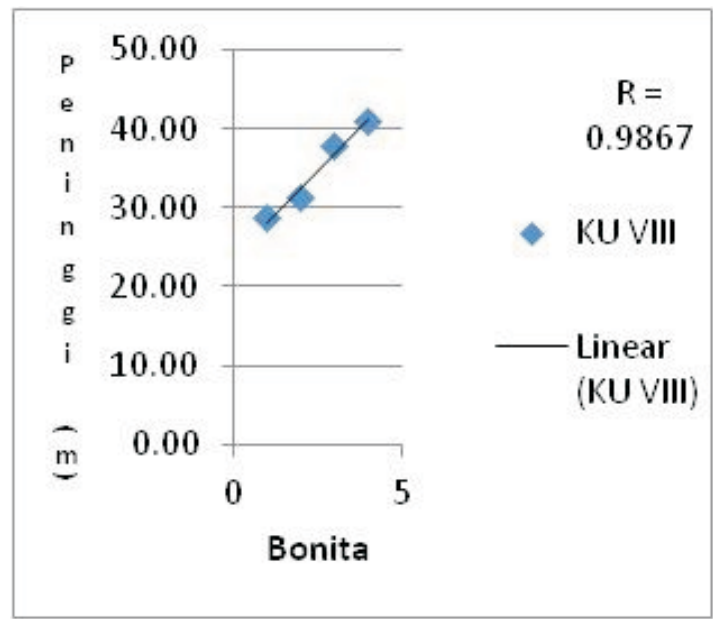

Gambar (Figure) 10. Peninggi KU VIII (The higest tree of KU VIII)

Berdasarkan grafik yang dilakukan dengan menggunakan program excel terlihat bahwa peninggi mempunyai hubungan erat dengan bonita, hal tersebut ditunjukkan oleh besaran nilai R (koefisien korelasi) yang memiliki nilai > $90 \%$.

\section{Teknik Analisis Statistika Sederhana dan Tranformasi Z-Fisher}

Pengujian keeratan hubungan yang dilakukan dengan menggunakan analisis statistika sederhana dan transformasi Z- Fisher dapat terlihat pada Tabel 1. 
Tabel(Table) 1. Keeratan hubungan peninggi dengan bonita dengan statistika sederhana dan transformasi Z Fisher (Corelation between the higest tree and site quality tested by simple statistic and Z Fisher transformation)

\begin{tabular}{|c|l|c|c|c|}
\hline No & \multicolumn{1}{|c|}{ Kelas Umur (KU) } & $\mathrm{R}^{*}$ & Z Hitung & Z Tabel \\
\hline 1 & KU II & 0,97 & $3,23^{*}$ & 2,09 \\
\hline 2 & KU III & 0,97 & $2,33^{*}$ & 2,09 \\
\hline 3 & KU IV & 0,91 & $2,13^{*}$ & 1,52 \\
\hline 4 & KU V & 0,91 & $2,62^{*}$ & 1,52 \\
\hline 5 & KU VI & 0,97 & $2,27^{*}$ & 2,09 \\
\hline 6 & KU VII & 0,99 & 1,33 & 1,38 \\
\hline 7 & KU VIII & 0,98 & 1,64 & 2,29 \\
\hline
\end{tabular}

Keterangan (Remark): R* = Nilai koefisien korelasi berdasarkan hasil perhitungan secara analisis statistika sederhana (Corelation coefficient value based on simple statistic analysis)

Dilihat dari nilai $\mathrm{R}$ yang dihitung berdasarkan statistika sederhana nilai $\mathrm{R}$ tersebut cukup baik atau dapat dikatakan bahwa peninggi mempunyai keeratan yang baik dengan bonita, tetapi apabila diuji dengan transformasi $\mathrm{Z}$ Fisher dengan hipotesa Ho $: \rho=0,7$ dan $\mathrm{H} 1: \rho>$ 0,7 , dengan kaidah keputusan $\mathrm{Z}$ hitung $\geq \mathrm{Z}$ tabel maka berarti hubungan antara peubah- peubah tersebut terjadi pada nilai $\mathrm{R}>0,7$, sedang apabila $\mathrm{Z}$ hitung $\leq \mathrm{Z}$ tabel berarti hubungan antara peubah-peubah tersebut terjadi pada nilai $\mathrm{R}<0,7$. Sehingga dari tabel tersebut ada tiga kelas umur KU II, III, IV, V dan VI yang mempunyai hubungan keeratan yang baik. Sedangkan KU VII dan VIII hubungan keeratannya tidak cukup baik. Dari apa yang telah diutarakan di muka secara umum penggunaan bonita untuk suatu evaluasi lahan (kualitas lahan) masih dapat digunakan.

\section{KESIMPULAN DAN SARAN}

\section{A. Kesimpulan}

1. Perubahan bonita secara umum sebesar $55 \%$ dengan perubahan menjadi lebih baik sebesar $12,5 \%$, bonita yang mengalami penurunan sebesar $42,5 \%$, sedangkan yang tetap sebesar $45 \%$.

2. Penurunan bonita berada pada selang KU II sampai KU VII.

3. Penggunaan Bonita untuk menilai kualitas lahan masih layak untuk digunakan, hal tersebut ditunjukkan oleh hubungan keeratan yang cukup tinggi sampai tinggi.

\section{B. Saran}

Perlu pengembangan evaluasi lanjut dan lebih detail tentang Kelas Penggunaan Lahan (KPL) guna penilaian lahan hutan jati, sehingga KPL dapat digunakan untuk pengevaluasian lahan kosong.

\section{DAFTAR PUSTAKA}

Akindele, S.O. 1991. Development of a Site Index Equation for Teak Plantations in Southwestern Nigeria. Journal of Tropical Forest Science 4(2): 162-169

Anwar, C. 2007. Prediction of Teak Bonita (Site Index) in Central Java, Indonesia, Base on The Soil Propeties. Journal of The Forestry Research Vol. 4 No. 1, March 2007; 9-18.

Biro Perencanaan dan Pengembangan Perusahaan, 2003. Penyusunan Rencana Pengaturan Kelestarian Hutan. Perum Perhutani Unit I Jawa Tengah, Semarang.

Putra Parthama I.B., S. Bustomi., D. Wahjono., Harbagung. dan H.Krisnawati. 1999. Petunjuk Teknis Penentuan Bonita Hutan Tanaman Industri. Badan Litbang Kehutanan dan Perkebunan. Pusat Penelitian dan Pengembangan Hutan dan Konservasi Alam, Bogor.

Puslitbang Perum Perhutani. 2007. Studi Tapak (Site) pada Pengelolaan Hutan Jati. Laporan Penelitian. Pusat Penelitian dan Pengembangan Perum Perhutani. 
Sajjaduzzaman, Md., M. Abdus Subhan, M. Ralph, N. Muhammad, dan T.K Muhammad. 2005. Site Index for Teak (Tectona grandis Linn. F.) in Forest Plantation of Bangladesh. International Journal of Agriculture and Biology. Vol.7, No.4.

Sakurai, K., Y. Yamada, T. Tulaphitak, K. Junthotai, C. Wacharintarat, S. Teejuntuk, and P. Sahunalu. 2002. Evaluation of Site Quality Index for Teak Plantation. In Thailand. Symposium of $17^{\text {th }}$ WCSS 14-21 August 2002. Thailand

Simon, H. 2007. Metode Inventori Hutan. Pustaka Pelajar. Yogyakarta.

Sukresno, U.H. Murtiono, A.B. Supangat, dan C.N.S. Priyono. 2003. Pengaruh Pengelolaan Hutan Jati Terhadap Tata Air : Studi Kasus di Sub DAS dalam Kawasan Hutan Jati (Modang dan Cemoro) dan Luar
Kawasan Hutan Jati (Grojogan). Temu lapang dan Ekspose Hasil-Hasil Penelitian UPT Badan Litbang Kehutanan Wilayah Sumatera. Palembang, 9-10 Desember 2003.

Upadhyay, A., E. Tron, L. Prem, and Sankhayan. 2005. Construction of Site Index Equation for Even Aged Stands of Tectona grandis (Teak) from Permanent Plot Data. In. India. Symposium Of " An Interdisciplinary Approach to Analyse The Dynamic of Forest and Soil Degradation and to Develop Sustainable Agro-Ecological Strategis for Fragile Himalayan Watershed". Forest Research Institute, Dehradun. India.

Yunianto, Z dan Muhadi. 2010. Erosi pada Hutan Jati. Warta Puslitbang Volume XIII No. 01 Januari 2010. Pusat Penelitian dan Pengembangan Perum Perhutani. 